\title{
Benefits of Agro Forestry Land Use in Nsukka Local Government Area, Enugu State, Nigeria
}

\author{
Ugwuoke Chukwuchebe Obiajulu \\ Lecturer \\ Department of Agricultural Economics \\ University of Nigeria, Nsukka \\ Opata Ifeyinwa Patience, $P h D$ \\ Lecturer \\ Department of Agricultural Economics \\ University of Nigeria, Nsukka \\ Ihedioha Nice Nneoma \\ Lecturer \\ Department of Agricultural Economics \\ University of Nigeria, Nsukka \\ Ume Chukwuma Otum \\ Lecturer \\ Department of Agricultural Economics \\ University of Nigeria, Nsukka \\ Corresponding Email: chukwuma.ume@unn.edu.ng
}

Received: November 6, 2018

Accepted: November 10, 2018

Online Published: November 17, 2018

\begin{abstract}
The natural environment of the Nsukka, is characterized by a combination of trees and grasses in different proportions. This readily provides conducive conditions for the combined cultivation of annual crops and perennial crops, or trees. But, some factors might have stalled the espousal and practice of agro forestry in Nsukka; this is because Nsukka until recently was generally inaccessible and lacked basic infrastructure. These have contributed negatively to result in wastage of farm products especially during harvest periods, and consequent loss of income to the farmers. The broad aim of the study was to analyze agro forestry land use practices of Nsukka farmers, assess the benefits, and draw up lessons and recommendations for sustainable agro forestry development in communitybased forestry projects by describing the socioeconomic characteristics of farmers, determining the type of agro forestry practiced in the area, identifying the reasons for farmers' participation in agro forestry practices, identifying the constraints to sustainable agro forestry in the area and the measures for tackling the constraints and determining the benefits of agro forestry to participating farmers and their communities at large. The results of the study showed that most farmers sale greater part of their produce as the only source of income and most farmers spend less because they use animal dropping as a source of fertilizer. The land tenure system of the entire study area is largely by inheritance, and land use is determined by the male head and, on whom the right of usage is vested. Similarly, the ownership, sponsorship and management of agro forestry farms are largely by the families.
\end{abstract}

Keywords: Agro-forestry, land ownership, land use, sustainable cropping, land tenure 


\section{Introduction}

One of the utmost challenges facing Nigerians in general, and the inhabitants of Nsukka, Enugu state precisely, is that of deforestation or vegetation loss. Agro forestry has been defined as an old practice, but a new science (Nair, 1983; Raintree, 1983; Huxley, 1986; Beets, 1990; Kang et al, 1999). The situation is not different in Nsukka as it has been practiced by peasant farmers over the years, though on a small holder basis. Certain factors might have either facilitated or hindered the practice of agro forestry in this territory.

The natural environment of the Nsukka, is characterized by a combination of trees and grasses in different proportions. This readily provides conducive conditions for the combined cultivation of annual crops and perennial crops, or trees. Moreover, the accessibility of grasses, shrubs and fodder from woody species further encourages the rearing of animals (Areola, 2008). The natural environment therefore favors agro forestry and the peasant farmers might have easily adopted it naturally.

On the other hand, some factors might have stalled the espousal and practice of agro forestry in Nsukka; this is because Nsukka until recently, was generally inaccessible and lacked basic infrastructure. Presently, most of the rural areas are still in this condition. These have contributed negatively to result in wastage of farm products especially during harvest periods, and consequent loss of income to the farmers. The implementation of agro forestry might have been an attempt by the peasant farmers to certify security against crop losses and wastage, as the agro forestry products will provide substitutions to food, income and other uses (Gaza 2005).

Another factor is the land tenure system. In Nsukka, the land tenure system is traditional and collective (Ejaro 2000). Land occupation and acquisition in Nsukka has remained largely traditional, despite the promulgation of the Land Use Decree of 1978 which vested all land in Nigeria to the Federal Government. This communal ownership of land especially in the rural parts of the territory has invigorated land fragmentation, and in some cases, the "slash and burn" system which is associated with large-scale deforestation, immigrant settlers of Nsukka have problems in acquiring land for cultivation, and they do so only on a temporary basis. These factors have all combined to hinder the large-scale adoption of agro forestry in the territory (Obi S. Nc 1963).

Also, the remote nature of most parts of Nsukka coupled with the absence of basic infrastructure, have for a long time enacted poverty within the territory. The enactment of poverty has therefore been an obstacle to farmers' investment in agriculture generally in terms of procurement of inputs, and particularly the procurement of tree seedlings and animal species for agro forestry practices (Abumere, 2008)

Nigerian forests have been enduring rapid depletion because of human influence. The problem exists at all levels. Onumadu (2002) has reported that the Federal Government of Nigeria, assisted by some international organizations, namely: European Economic Community, World Bank, established agro forestry projects to check the risk of deforestation in Nigeria. Despite these efforts, the problems of deforestation together with the attendant effects seem to continue. There are little, or no research previously carried out in the study area (Nsukka) in the nearest time past, as a result, the need to heighten level of awareness among researchers about the potentials of agro forestry.

In Nigeria, environmental degradation ensuing from increased soil erosion, deforestation or vegetation loss and hydrological changes leading to loss of productivity of land is also being tackled through agro forestry projects (Onumadu et al., 2001). Agro forestry is mainly an incorporation of the forestry programs into rural farm activities of the farmers. The main focus is on the sustainability of the environment with prominence on the desirable ways in which farmers can utilize the land to prevent it from degrading.

Apart from ensuring maximum exploitation of land resources for adequate provision of food, shelter and capital, agro forestry also checks environmental hazards like erosion, desertification, global warming, and ozone depletion acid rains among others. This study therefore will provide a basis for the design of agro forestry practices that would fit into the farmers' system and experience. Finally, the study would also serve as a reference material for researchers and students who may wish to conduct further study on this subject or related topics Therefore, the gap required to be filled is articulated within the following research questions:

(i) What are the benefits of agro forestry, to participating farmers, as well as the community?

(ii) What types of agro forestry are widely practiced in the study area? 
(iii) Why do farmers participate in agro forestry in the study area?

(iv) What problems are encountered and what measures are being used to tackle the problems? How is the ownership of land and the tree tenure system of the area?

The broad aim of the study is to analyze agro forestry land use practices of Nsukka farmers, assess the benefits, and draw up lessons and recommendations for sustainable agro forestry development in community-based forestry projects.

\section{Methodology}

\subsection{The Study Area}

The study was done in Nsukka Local Government Area of Enugu state. Nsukka Local Government Area lies between longitudes $7^{\circ} 13^{\prime} 00^{\prime \prime}-7^{\circ} 35^{\prime} 30^{\prime \prime}$ and latitudes $6^{\circ} 43^{\prime} 30^{\prime \prime}-7^{\circ} 00^{\prime} 30^{\prime \prime}$ in Enugu State, South-eastern Nigeria. (NBS 2006) Nsukka has an area of $1,810 \mathrm{~km}^{2}$ and a population of 309,633 at the 2006 census. Nsukka Local Government Area is made up of 16 communities with moderately rolling plains and hills. It shares boundaries with Igbo-Eze south Local Government Area and Udenu Local Government Area to the east, Igbo-Etiti Local Government Area to the south and Benue state to the North. It also has a boundary with Kogi state. The area has tropical climate with temperature range of between $26^{\circ} \mathrm{c}$ and $28^{\circ} \mathrm{c}$ and average annual rainfall of between $3000-$ $3500 \mathrm{~mm}$ per year. Farming is the major mode of economic activity.

\subsection{Sampling Procedure}

Sampling was done using two stage random sampling technique. The first stage involves a random sampling of five (5) communities out of the sixteen in the local government area.

The second stage involves selection of respondent from each of the communities. From the five communities, 10 farmers were randomly selected for the study, giving a sample size of fifty (50) respondents

\subsection{Data Collection}

Data for this study was obtained from both primary and secondary sources. A well-structured questionnaire for the collection of primary data, which was administered to the selected farmers from the five research communities. The questionnaire was divided into five incomes and other socio-economic characteristics of the farmers. Nature and types of agro forestry and constraints, that is, problems encountered in both tree and animal production, etc.

The secondary data was obtained from library research, internet, annual reports and other relevant information useful to research

\subsection{Measurement of variables}

The questionnaire was divided into five sections based on the objectives of the study. First objective was aimed at obtaining information on the socio-economic characteristic of the respondents in the study area. The socioeconomic characteristics of the respondents were measured and operationalized as follows:

Sex: The sexes of the respondents were recorded at nominal level as male (1) or female (2).

Age: the respondents were asked to give their age in years, after which it was grouped as follows < 20,21-30years, 31-40years, 41-50, 51-60, 61years and above.

Marital status: The respondents were asked to indicate their marital status as single (1), married (2), divorced (3), widowed (4), and separated (5).

Level of formal education: The respondents were asked to indicate their level of formal education as follows: No formal education (1), Primary school incomplete (2), Primary school completed (3), Secondary school incomplete (4), Secondary school completed (5), Vocational education (6), and others. 
Secondary occupation: The farmers were asked to indicate their secondary occupations as farming, civil service, trading, artisan and others.

Religion: Respondents were asked to indicate their belief practices namely Christianity, Islam and traditional religion and others.

Farming experience: farmers were asked to give the average number of years he/she has spent in farming.

Income: Respondents were asked to give their estimated annual income generated from agricultural and nonagricultural activities, and the total annual income generated. Other objectives follow similar pattern.

\subsection{Data Analysis}

Data collected from the field was analyzed using simple statistical description such as means, percentages, frequency distribution, tabulation and gross margin analysis; the Statistical Package for Service and Solution (SPSS) constitute the software package was used for the analysis.

Example of percentage and frequency distribution:

$\underline{\text { No of respondents who completed primary school }} \times \underline{100}$

Total number of respondents

Example of gross margin:

Gross margin $=$ Total Revenue - Total Cost

\section{Results and Discussion}

\subsection{Socio-Economic Characteristics of Respondents}

This section borders on the socio-economic features of the farmers in the study area. This was measured by characteristics such as sex, size of household, age, marital status, educational level, occupation (both major and minor), farm size, livestock size, farming experience, frequency of contacts with extension agents, annual income etc.

Age plays a significant role in farm household's ability to respond appropriately to agro forestry and other emerging trends in the agricultural sector both at the individual levels and at the national level. As shown in table 1 respondents representing 56\% aged 50years and below while the rest $44 \%$ were older. Shows that majority are of youthful age

This further implies that the youth segment of the study is more into agriculture than the other segments and may reflect the population of study.

Table 1 shows the distribution of respondents according to sex. The table shows that majority (60\%) of the respondents are males while the remaining (40\%) are females. This finding is indicative of the fact that male household heads out numbered the female household heads and so do have more access to land and other resources. The sex of the household head could determine consumption level of the household and access to other resources such as land in the south eastern part of Nigeria.

Table 1. socio-economic characteristics of the respondents

\begin{tabular}{lll}
\hline Age & Frequency & Percentage \\
50 and below & 28 & 56 \\
Above 50 & 22 & 24 \\
Total & 50 & 100 \\
Gender & Frequency & Percentage \\
\hline
\end{tabular}




\begin{tabular}{lll}
\hline Male & 30 & 60 \\
Female & 20 & 40 \\
Total & 50 & 100 \\
Religion & Frequency & Percentage \\
Christianity & 49 & 98.0 \\
Traditional religion & 1 & 2.0 \\
Total & 50 & 100 \\
Marital status & Frequency & Percentage \\
Single & 7 & 14.0 \\
Married & 37 & 74.0 \\
Widowed & 6 & 12.0 \\
Total & 50 & 100 \\
Level of Education & Frequency & Percentage \\
No formal education & 15 & 30 \\
Primary Education attempted & 4 & 8 \\
Primary Education completed & 10 & 20 \\
Secondary Education attempted & 13 & 26 \\
Secondary Education completed & 7 & 14 \\
Vocational education & 1 & 2 \\
Total & 50 & 100 \\
Major occupation & Frequency & Percentage \\
Farming & 43 & 86.0 \\
Trading & 3 & 6.0 \\
Civil service & 1 & 2.0 \\
Artisan & 3 & 6.0 \\
Total & 50 & 100 \\
Minor occupation & Frequency & Percentage \\
Farming occupation & 11 & 22.0 \\
Non-farm business & 39 & 78.0 \\
Total & 50 & 100 \\
\hline
\end{tabular}

Source: field survey, 2018

Entries in Table 1 show that majority of the respondents were Christians while only $2.0 \%$ practiced traditional religion, this can be attributed to the large population of south easterners that practice Christianity

Marital status has a huge impact on agricultural practices as farming activities may largely be dependent on this. An individual who is married and has procreated for instance would have less need to wards employing farm labor from outside his/her household thus making the marital status of individuals a pertinent factor in agricultural practices. For this study therefore, table 1 shows the distribution of farm households based on respondents' marital status. Majority (74.0\%) of the respondents were married while $14.0 \%$ and $12.0 \%$ were single and widowed respectively. Taken that a greater number of respondents are married may perhaps expand their labor force during farming activities

Usually, the size of farm households affects productivity, consumption, technical efficiency, farm income among several others. Fig below shows the frequency of distribution of the respondents according to household size. These reasons underscore the importance of farm household size in the area of study.

The figure below shows the distribution of farm household in the study area. Result revealed that a little over half (52\%) of the sampled respondents representing 26 respondents have 6-10 persons in their household, on the other hand household size of between $11-15,1-5$ and 16 and above had $28.0 \%, 12.0 \%$ and $8.0 \%$ respectively.

The Fig. below result suggests that majority of the sampled respondents have a moderate house hold size of 6-10 members which could be because of some other socio-economic factors like monogamous marriage (one man, one wife), religion (encourages monogamy) and economic factors (high cost of living) compel people to have a moderate family size with 6-10 persons. This situation is also congruent with the realities of the south eastern Nigeria. Also, can be because they are still in child bearing age and so could have more children. 


\section{Distribution of Farm Household Size}

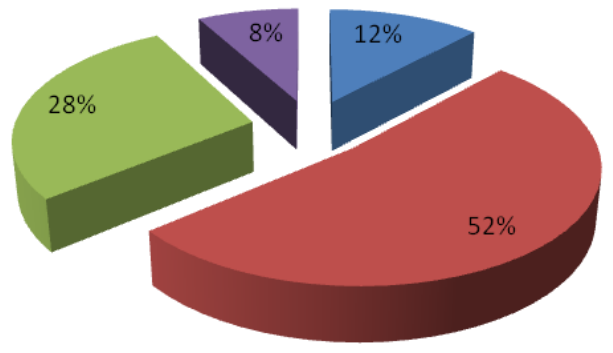

1 to 5

- 6 to 10

11 to 15

16 and above

Figure 1: Pie Chart showing the distribution of farm household in the area of study.

Individual's educational levels primarily impact on knowledge, attitudes and practices that are related to agro forestry practices.

Table 1 that $30 \%$ of the 50 respondents have no formal education. Whereas $8 \%, 20 \%, 26 \%$ and $14 \%$ also have Primary Education attempted, Primary Education completed, secondary education attempted, and secondary education completed respectively, the remaining (2\%) respondents have vocational education. The result below suggests that individuals who hold primary, secondary and tertiary certificates do not really differ from each other; going by the proximity in percentages which is indicating a 'mix' of educational levels among the sampled respondents and can be understood from the huge presence of educational institutions both within and close (outside) to the study area.

The major occupation of respondents is the primary economic activity which the respondents engage in and acquire wealth or income for sustenance of their livelihood and investments.

Table 1 discloses the distribution of respondents according to major occupation. Finding showed that a majority (86\%) are primarily farmers while $2 \%$, are civil servants; $6 \%$ are into trading and the remaining $6 \%$ of the respondents, artisan. The result from table 1 suggests that farming activities is a predominant occupation among respondents and perhaps reflective of the occupational realities among the study population in the local government area. The uncertainties that accompany farming activities can have far reaching consequences on the survival and livelihood of farmers; hence the need to engage in other secondary activities that could enhance the supportive capacity of farmers becomes crucial. The minor occupation by implication therefore refers to all other secondary or supportive engagements undertaken by sampled farmers in the area of study in order to increase their income. Table 1 presents the distribution of respondents according to their minor occupation. Judging from the table 1, an over whelming majority (78\%) of the entire respondents engage in non-farming business as their minor occupation. On the other hand, $22 \%$ engage in farming which they see as a minor occupation. This also indicates that non-farming business plays a supportive role to agricultural activities.

Table 2 Other socio-economic characteristics

Monthly income from major occupation ( $\mathbb{*}$ )

$1000-10000$

$10001-20000$

20001-30000

30001 and above

Annual income from minor occupation

$\leq 50000$

50001-100000
18

23

8

12

21

12
36

46

16

47.7

27.3 


\begin{tabular}{|c|c|c|}
\hline $100001-150000$ & 7 & 15.0 \\
\hline $150001-200000$ & 3 & 6.8 \\
\hline 250000 and above & 1 & 3.2 \\
\hline \multicolumn{3}{|c|}{ Annual income from major occupation $(\mathbb{N})$} \\
\hline$\leq 100000$ & 9 & 18.0 \\
\hline $100001-200000$ & 23 & 46.0 \\
\hline 200001-300000 & 14 & 28.0 \\
\hline $300001-400000$ & 3 & 6.0 \\
\hline 400001 and above & 1 & 2 \\
\hline \multicolumn{3}{|c|}{ Monthly income from minor occupation ( $(\mathbb{N})$} \\
\hline$\leq 5000$ & 31 & 62 \\
\hline 5001-10000 & 14 & 28 \\
\hline $10001-15000$ & 4 & 9.3 \\
\hline 20000 and above & 1 & 0.7 \\
\hline \multicolumn{3}{|l|}{ Source of labor } \\
\hline Individual & 26 & 52.0 \\
\hline Family & 24 & 48.0 \\
\hline \multicolumn{3}{|l|}{ Size of farmland (ha) } \\
\hline Homestead & Frequency & Percentage \\
\hline$\leq 0.5$ & 29 & 58.0 \\
\hline $0.6-1$ & 21 & 42.0 \\
\hline Outlaying farms & Frequency & Percentage \\
\hline$\leq 5$ & 18 & 36 \\
\hline $6-10$ & 32 & 64 \\
\hline Access to extension service & Frequency & percent \\
\hline No & 50 & 100 \\
\hline \multicolumn{3}{|l|}{ Method of land acquisition } \\
\hline Purchase & 8 & 16.0 \\
\hline Inheritance & 42 & 84.0 \\
\hline Total & 50 & 100 \\
\hline Years in agro forestry & Frequency & Percentage \\
\hline$\leq 20$ & 8 & 16 \\
\hline $21-40$ & 20 & 40 \\
\hline 41 and above & 22 & 44 \\
\hline Total & 50 & 100 \\
\hline
\end{tabular}

Source: field survey, 2018

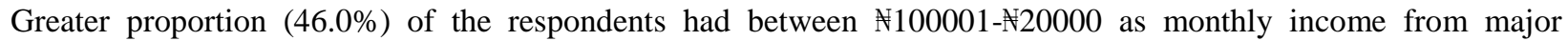
occupation followed by $36.0 \%$ of respondents that had between $11000-110000$. Similarly, $16.0 \%$ and $2.0 \%$ of the respondents had $\$ 20001-\$ 30000$ and $\$ 30001$ and above respectively. The income levels of farm household have a significant impact on procurement of necessary tools and other technologies that re-impact on agricultural activities, efficiency, productivity, financial management skills and other aspects of their livelihood. The distribution of respondents according to their annual income is shown in table 2.

Result from table 2 shows that Greater proportions (46\%) of the respondents had annual income from major occupation as 100001-200000 while 28\%, 6\%,18\% and 2\% had $\mathrm{A} 200001-300000,-\mathrm{N} 300001-400000, \mathrm{~A} \leq 100000$ respectively. This result therefore suggests that majority of the entire respondents earn just enough. This outcome may also be reflective of the fact that though agricultural practice is predominant in the nation, it does not provide adequate remuneration that matches the input of agricultural labor.

Majority (55.8\%) had monthly income from minor occupation of $\leq \mathbb{N 5 0 0 0}$ and $27.3 \%$ had between $\mathrm{N} 5001$ - $\mathrm{A} 10000$. Also, $23.0 \%$ and $9.3 \%$ had between $\$ 20000$ and above and $\$ 10001-\mathbb{N} 15000$ above. Greater proportion 
(47.0\%) of the respondents had annual income from minor occupation of $\leq \mathbb{A 5 0 0 0 0}$ followed by $27.3 \%$ and $15.0 \%$

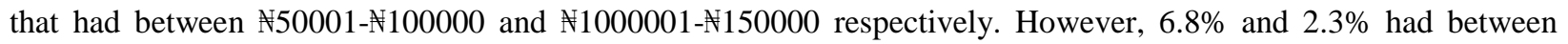
$\$ 150001-\$ 200000$ and $\$ 200001$ and above respectively. Greater proportion (52.0\%) of the respondents used individual labor and source of labor while $48.0 \%$ used family labor.

The economic importance of farm size cannot be over emphasized in agro forestry. The reason for this is probably due to the fact large or small farm size if appropriately utilized can improve farm productivity and enhance agricultural sufficiency even in the face of unexpected events. This was considered paramount to the understanding of this study. Table 2 therefore shows the distribution of respondents according to farm size.

Results from table 2 depicts that $58.0 \%$ of the entire (50) respondents have a farm size $\leq 0.5$ ha in their homestead farm as opposed to $64 \%$ of the respondent having above 0.6 ha in outlying farms, whereas $42 \%$ representing 21 respondents have farm sizes of $0.6-1$ ha in homestead farm as opposed to $36 \%$ having $\leq 5$ ha in outlying farm. Suggesting that there is limited area of land available for agricultural purposes in their homestead farm and vast area of land are available in their outlying farms in the area of study.

It is common knowledge that extension agents' roles are to equip farmers with the needed working knowledge of the main elements of the agricultural system, the frequency of contact between farmers and agricultural extension workers may be of significance in ensuring the best agricultural practices that is particularly suited for the farmer's environment. The frequency of contact between respondents and extension agents was therefore measured. Result showed that extension agents are scarce or don't visit the farmers at all. Majority (84.05) acquire land through inheritance while $16.0 \%$ acquired through purchase. This shows without doubt that most of the farm land were handed down to them by their fore fathers. The implication of this is that in situation where inherited land is small, mechanization is impaired, it also results to land fragmentation.

The table shows that greater proportion $(46.8 \%)$ of respondents had agro forestry experience of 41 years and above while $42.6 \%$ and $10.6 \%$ had between $21-40$ years and $\leq 20$ years respectively. All (100.0\%) of the respondents indicated that the source of capital for agro forestry activities is personal savings. Data on Table 2 show that greater

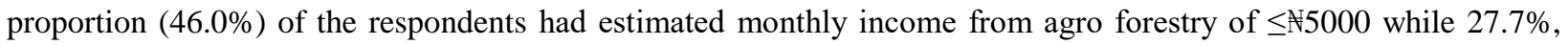
$19.6 \%$ and $6.4 \%$ had $\$ 5001-\$ 10000, \$ 100001-\$ 15000$ and $\$ 15000$ and above.

Majority $(55.3 \%)$ of the respondents indicated that their estimated monthly income from non-agro forestry is $\leq$ \$5000. Also, 22.3\%, 18\% and 4.4\% had between \$5001-\$10000, $\$ 10001-\$ 15000, \$ 15001$ and above. Greater proportion (42.0\%) of respondents had an estimated monthly income of between $\mathrm{A} 20001-\mathrm{A} 30000$ while $26.0 \%$ and

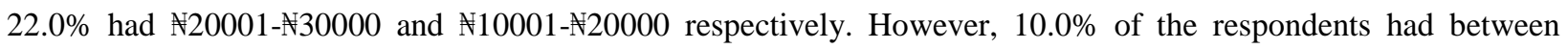
$\$ 30001-\$ 40000$ and $\$ 40001$ and above each. Greater proportion (38.0\%) of the respondents had estimated annual income of between 100001-200000. Also 26.0\% had between $\$ 300001-\$ 400000$ while $18.0 \%, 12.0 \%$ and $6.0 \%$ had $\star 200001-\$ 300000, \leq \$ 100000$ and between $\$ 400001$ and above

\subsubsection{Gender aspect in agro forestry}

All (100.0\%) of the respondents said women do not own tree in the village. This is in line with custom of the people of south east part of the country. All (100.0\%) indicated women can buy tree in the village. Once a woman has the finance, she can buy any tree she desires. Majority of the respondents $94 \%$ indicated women can sell tree while only $6.0 \%$ indicated on the contrary. 


\subsubsection{Decision making on household owned trees}

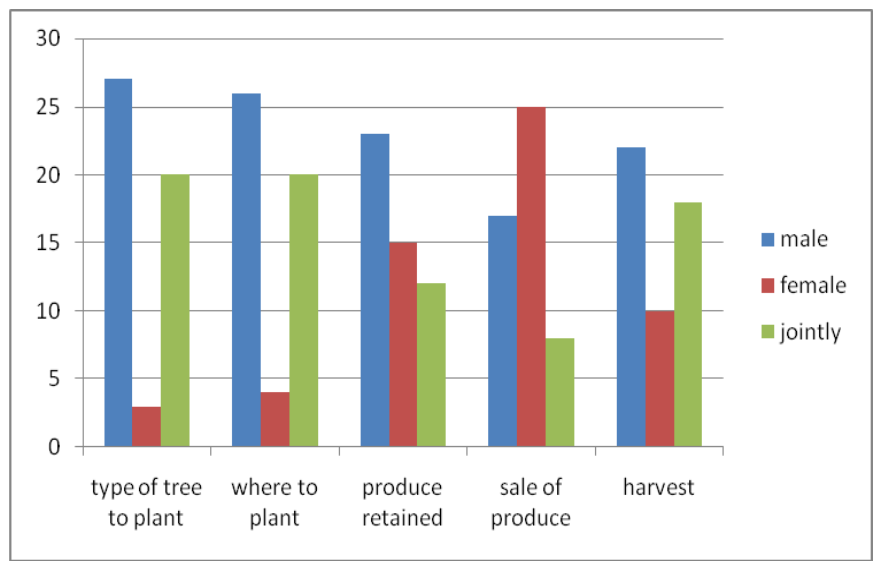

Figure 2. Decision making on household in Agro forestry practice

Greater proportion $(54.0 \%)$ of the respondents indicated that decision making on the type of trees to plant is done by male while $40.0 \%$ is done jointly (both male and female). However, only $6.0 \%$ of the decision is done by the female. Greater proportion $(52.0 \%)$ of the respondents also indicated that decision on where to plant trees is done by male while $40.0 \%$ is done jointly and $8.0 \%$ by women.

Decision on produce to be retained by household as indicated by greater proportion (46.0\%) of the respondent is done by male. Also, $30.0 \%$ and $24.0 \%$ are done by female and jointly respectively. About $50.0 \%$ of the respondents indicated that decision on sale of produce is done by female while $34.0 \%$ is by male and $16.0 \%$ is jointly. Greater proportion $(44.0 \%)$ of the respondents indicated that decision on harvest of tree products is done by male while $36.0 \%$ is done jointly and $20.0 \%$ is by female.

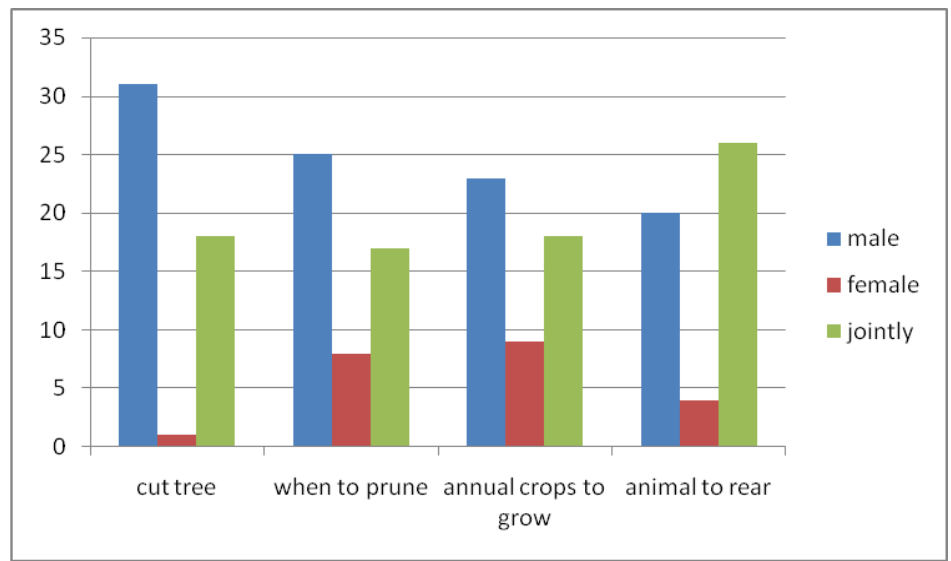

Figure 3.Continuation

Decision on cutting down of trees is down majorly by male as indicated by the majority (62.0\%) of the respondents. About $36.0 \%$ of the respondents indicated the decision is done jointly while $2.0 \%$ is done by female. Greater proportion $(50.0 \%)$ of the respondents indicated that the decision on when to prune trees is done by male while $34.0 \%$ is by female and $16.0 \%$ by male.

The decision on annual crop to be grown according to the greater proportion (46.0\%) of the respondents is done by male while $36.0 \%$ o and $18.0 \%$ indicated it is done and jointly by female respectively. The decision on type of animal to rear is mainly done through joint decision and by male as indicated by $52.0 \%$ and $40.0 \%$ of the respondents respectively. Only $8.0 \%$ of the decision is done by female. 


\subsection{Type of Agro forestry practiced}

Table 3 showing details of Agro forestry practiced by respondents

\begin{tabular}{|c|c|c|}
\hline Type of animal reared (multiple response) & frequency & Percent \\
\hline Goat & 29 & 56.9 \\
\hline Poultry & 13 & 25.5 \\
\hline Pig & 15 & 29.4 \\
\hline \multicolumn{3}{|c|}{ Where do tree and shrubs occur in the landscape (multiple response) } \\
\hline Home compound & 14 & 27.5 \\
\hline Range land & 14 & 27.5 \\
\hline River bank & 10 & 19.6 \\
\hline Crop land & 11 & 21.6 \\
\hline Pastures & 9 & 17.6 \\
\hline Forest & 14 & 27.5 \\
\hline Property boundaries & 2 & 3.9 \\
\hline \multicolumn{3}{|l|}{ Arrangement of trees (multiple response) } \\
\hline Lines & 21 & 42. \\
\hline $\begin{array}{l}\text { Dispersed } \\
\text { most important tree crops grown in the homestead }\end{array}$ & 29 & 58 \\
\hline Cashew (Anacardiun occidentale) & 40 & 78.4 \\
\hline Ube (pyrus spp) & 37 & 72.5 \\
\hline Paw paw (Carica papaya) & 1 & 2.0 \\
\hline Mango (Mangifera indica) & 37 & 72.5 \\
\hline Guava (Psidiun guajava) & 6 & 11.8 \\
\hline Banana (Musa spp) & 9 & 17.6 \\
\hline Plantain (Musa spp) & 9 & 17.6 \\
\hline Coconut (Cocos nucifera) & 2 & 3.9 \\
\hline Oil palm (Elaeis guineensis) & 6 & 11.8 \\
\hline $\begin{array}{l}\text { Orange (Citrus sinensis) } \\
\text { most important food crops grown in the homestead }\end{array}$ & 11 & 21.6 \\
\hline Maize (Zea mays) & 37 & 72.5 \\
\hline Cassava (Manihot utilisima) & 31 & 60.8 \\
\hline Yam (Dioscorea spp) & 29 & 56.9 \\
\hline Garden egg (Solanum melongena) & 25 & 49.0 \\
\hline Cocoyam (Colocasia esculenta) & 24 & 47.1 \\
\hline Black beans (Phaseolus vulgaris) & 6 & 11.8 \\
\hline $\begin{array}{l}\text { Cucumber (Cucumis sativus) } \\
\text { most important tree crops grown in outlay farms }\end{array}$ & 4 & 7.8 \\
\hline Ube (pyrus spp) & 28 & 54.9 \\
\hline Cashew (Anacardiun occidentale) & 20 & 39.2 \\
\hline Mango (Mangifera indica) & 13 & 25.5 \\
\hline Orange (Citrus sinensis) & 12 & 23.5 \\
\hline Coconut (Cocos nucifera) & 9 & 17.6 \\
\hline Oil palm (Elaeis guineensis) & 9 & 17.6 \\
\hline Banana (Musa spp) & 5 & 9.8 \\
\hline Guava (Psidiun guajava) & 5 & 9.8 \\
\hline $\begin{array}{l}\text { Pawpaw (Carica papaya) } \\
\text { most important food crop grown in outlay farms }\end{array}$ & 5 & 9.8 \\
\hline Cassava (Manihot utilisima) & 36 & 70.6 \\
\hline Maize (Zea mays) & 29 & 56.9 \\
\hline Coco yam (Colocasia esculenta) & 27 & 52.9 \\
\hline Yam (Dioscorea spp) & 22 & 43.1 \\
\hline Garden egg (Solanum melongena) & 22 & 43.1 \\
\hline Okro (Abelmoschus esculentus) & 8 & 15.7 \\
\hline
\end{tabular}




\begin{tabular}{lll}
\hline Cucumber (Cucumis sativus) & 1 & 2.0 \\
Method of tree establishment & 30 & 60 \\
Deliberately planted & 12 & 24 \\
Sprouted on its own & 8 & 16 \\
during bush clearing & & \\
\hline
\end{tabular}

Source: Field Survey, 2018

\subsubsection{Type of agro forestry practiced}

The bar chat below shows that the major type of agro forestry practiced as indicated by majority $(62.0 \%)$ of the respondents was agro silvopastoral (combination of food crop, pasture and tree) while agro silviculture (use of crops and trees) was practiced by $38.0 \%$.

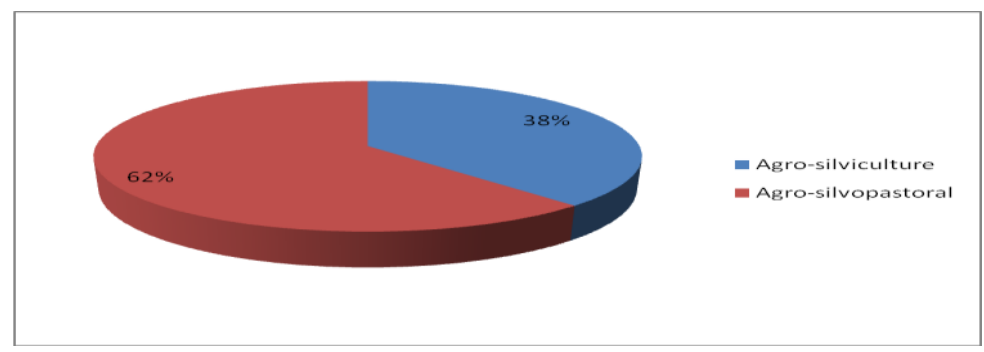

Figure 4. Type of agro forestry practiced

The major type animal reared as indicated by the majority (56.9\%) of the respondent in table 3 above was goat while $29.4 \%$ and $25.5 \%$ reared pig and poultry respectively

Greater proportion (27.5\%) each of the respondents indicated that trees and shrubs occur in home compound, range land and forest respectively. While $21.6 \%, 19.6 \%$ and $17.6 \%$ indicated tree and shrubs occur in crop land, river bank and pastures respectively. However, only $3.9 \%$ of these occur in property boundaries. Greater proportion (58.0\%) of the respondents indicated that trees are arranged in dispersed form while $42 \%$ arrange in lines.

Data on table 3 above... indicated that the major important tree crop grown in the homestead as indicated by majority (78.4\%) of the respondent is cashew. Similarly, $72.5 \%$ of the respondents each grow mango and ube while $62.7 \%, 41.2 \%$ and $21.6 \%$ grow ujiri, oroma and orange respectively. Also, 9.0\% each accounted for respondents that grow nkwu, banana and plantain respectively. On the other hand, $11.8 \%$ each indicated they grow guava and oil palm while $7.8 \%, 3.9 \%$ and $2.0 \%$ accounted for respondents that grow aki, coconut and pawpaw respectively.

Data on table 3 above... indicated that the major important food crop grown in the homestead as indicated by majority (72.5\%) of the respondent is maize. Similarly, $60.8 \%$ of the respondents each grow yam, while 56.9\%, 49\% ,47.1\%,19.6\%,11.8 and 7.8 grow garden egg, cocoyam, pepper, black beans, and cucumber respectively. On the other hand, $11.8 \%$ each indicated they grow guava and oil palm while $7.8 \%, 3.9 \%$ and $2.0 \%$ accounted for respondents that grow aki, coconut and pawpaw respectively.

Data on table 3 shows that $60 \%$ of farmers deliberately planted their crops and trees, $24 \%$ sprouted on its own while $16 \%$ during bush clearing

\subsection{Reasons for participating in agro forestry}

Table 4: Percentage distribution of farmers based on reasons for participating in agro forestry practices

\begin{tabular}{lll}
\hline Reasons & Frequency & Percentage \\
\hline Economic reasons & 50 & 100.0 \\
Decrease of inputs & 41 & 82.0 \\
Entails more productivity & 50 & 100.0 \\
As a source of income & 50 & 100.0 \\
It is cheaper & 48 & 96.0 \\
\hline
\end{tabular}




\begin{tabular}{lll}
\hline It enriches the soil & 50 & 100.0 \\
Encourages afforestation & 50 & 100.0 \\
To use as collateral & 35 & 70.0 \\
Protect the soil from erosion & 46 & 92.0 \\
\hline
\end{tabular}

Source: Field Survey, 2018

Data on table 4 shows clearly that all the respondents agree that economic reason, entails more productivity, as a source of income, it enriches the soil, encourages afforestation are the major reasons they engage in agro forestry, most of the respondents believe that they can hardly gain collateral with their agro forestry practice from financial institutions

\subsubsection{Constraints to agro forestry}

Table 5: Mean distribution of farmers on constraints to agro forestry

\begin{tabular}{lll}
\hline Constraints to agro forestry & Mean & Standard deviation \\
\hline High cost of agro-chemicals & $3.38^{*}$ & 0.490 \\
Poor access to information about climate change & $3.14^{*}$ & 0.783 \\
Land ownership & $2.82^{*}$ & 0.774 \\
Costs associated with the adequate & $2.86^{*}$ & 0.783 \\
Unfavorable policy on agro forestry & $2.78^{*}$ & 0.582 \\
Pest and diseases attack & $2.98^{*}$ & 0.714 \\
Poor road/transportation & $3.64^{*}$ & 0.485 \\
Poor extension contacts & $3.44^{*}$ & 0.705 \\
Poor access to capital & $3.46^{*}$ & 0.706 \\
Post-harvest losses & $3.49^{*}$ & 0.505 \\
Inadequate storage facilities & $3.48^{*}$ & 0.614 \\
Lack of agricultural input/subsidies & $3.14^{*}$ & 0.808 \\
Cultural barrier (women not owing land) & $2.88^{*}$ & 0.918 \\
Limited access to health care/facility & $2.66^{*}$ & 1.022 \\
Low price of agricultural produce & $3.02^{*}$ & 1.204 \\
Poor/hazardous working condition & $3.54^{*}$ & 0.542 \\
Theft & $3.62^{*}$ & 0.490 \\
Tax charged for using farmland & 2.44 & 1.128 \\
Insufficient land & $2.69^{*}$ & 0.713 \\
Land tenure insecurity that discourages migrant farmers from & $2.86^{*}$ & 0.904 \\
embarking on large scale farming & $2.92^{*}$ & 1.047 \\
Long distance from farmland & $3.22^{*}$ & 0.616 \\
Infertile land & $3.22^{*}$ & 0.679 \\
Poor market for Agric & $2.88^{*}$ & 1.043 \\
Lack of formal Edu & $2.36^{*}$ & 1.174 \\
Discrimination and social isolation & &
\end{tabular}

Source: Field Survey, 2018

Data on Table $5 \ldots$ shows that the major constraints to agro forestry include poor road/transport $(\mathrm{M}=3.64)$, theft $(\mathrm{M}=3.62)$, poor/hazardous working condition $(\mathrm{M}=3.54)$, poor harvest lost $(\mathrm{M}=3.49)$, inadequate storage facilities $(M=3.48)$ poor access to capital $(M=3.46)$, poor extension contact $(M=3.44)$, high cost of agro chemicals $(M=3.38)$, poor access to information about climate change $(\mathrm{M}=3.14)$, lack of agricultural input/subsidies $(\mathrm{M}=3.14)$, low price of agricultural produce $(\mathrm{M}=3.02)$, land ownership $(\mathrm{M}=2.82)$, cost associated with the adequate $(\mathrm{M}=2.86)$, Pest and 
diseases attack (M=2.98), Cultural barrier (women not owing land) $(\mathrm{M}=2.88)$, Land ownership ( $\mathrm{M=2.82}$ ), unfavorable policy on agro forestry $(M=2.78)$, Insufficient land $(M=2.69)$, tax charged for using farmland $(M=2.44)$. Poor road/transport $(M=3.64)$, poor harvest lost $(M=3.49)$, inadequate storage facilities $(M=3.48)$ and long distance from farmland $(\mathrm{M}=2.92)$.

Others include, poor access to capital $(\mathrm{M}=3.46)$, high cost of agro chemicals $(\mathrm{M}=3.38)$, lack of agricultural input/subsidies $(M=3.14)$, low price of agricultural produce $(M=3.02)$, cost associated with the adequate $(M=2.86)$, tax charged for using farmland $(\mathrm{M}=2.44)$ and poor market for agricultural produce $(\mathrm{M}=3.22)$

Also, other constraint as identified by farmers include: poor/hazardous working condition (M=3.54), Land ownership ( $\mathrm{M}=2.82)$, unfavorable policy on agro forestry $(\mathrm{M}=2.78)$, Insufficient land $(\mathrm{M}=2.69)$, Land tenure insecurity that discourages migrant farmers from embarking on large scale farming $(\mathrm{M}=2.86)$, discrimination and social isolation $(M=2.36)$, and infertile land $(M=3.22)$. In addition to these, extension contact $(M=3.44)$, poor access to information about climate change $(\mathrm{M}=3.14)$ Lack of formal education $(\mathrm{M}=2.88)$ equally constitute to challenges to agro forestry.

\subsection{Farmers' perception of benefits of agro forestry}

Table 6: Mean distribution of farmers' perception of benefits of agro forestry

\begin{tabular}{lll}
\hline Benefits of agro forestry & Mean & Standard deviation \\
\hline Fight soil erosion & $3.38^{*}$ & 0.490 \\
Provision of raw material & $3.36^{*}$ & 0.485 \\
Medicinal purposes & $3.34^{*}$ & 0.717 \\
Maintenance of genetic diversity & $3.34^{*}$ & 0.658 \\
Increase land productivity & $3.42^{*}$ & 0.499 \\
Food provision & $3.46^{*}$ & 0.503 \\
Reduces poverty level & $3.52^{*}$ & 0.505 \\
Increases source of income for the farmer & $3.50^{*}$ & 0.505 \\
Improved economic and social condition in Rural area & $3.40^{*}$ & 0.495 \\
Ensures better land management & $3.54^{*}$ & 0.503 \\
Provision of shade & $3.48^{*}$ & 0.931 \\
Enriches the soil/source of manure & $3.74^{*}$ & 0.443 \\
Local climate and air regulations & $3.08^{*}$ & 0.944 \\
Aesthetic quality & $2.90^{*}$ & 0.931 \\
Wind break & $3.26^{*}$ & 1.065 \\
Watershed mgt & $2.92^{*}$ & 0.986 \\
All year-round income & $3.76^{*}$ & 0.555 \\
Use of tree as collateral & $2.30^{*}$ & 1.159 \\
\hline Source: Field Survey, & &
\end{tabular}

Source: Field Survey, 2018

Data on table 6 above ... shows that the farmer's perceived benefits to agro forestry include: all year round income $(M=3.76)$ enrich soil with manure $(M=3.74)$, fight soil erosion $(M=3.38)$, increase land productivity $(M=3.42)$, maintenance of gen diversity $(M=3.34)$, ensure better land management $(M=3.54)$, ), provision of shade $(M=3.48)$, local climate and air regulation $(\mathrm{M}=3.08)$, wind break $(\mathrm{M}=3.26)$

Others include provision of raw materials $(\mathrm{M}=3.36)$, provision of food $(\mathrm{M}=3.46)$, reduce poverty level $(\mathrm{M}=3.52)$, increases source of income for the farmer $(\mathrm{M}=3.50)$, improved economic and social condition in rural area $(M=3.40)$, aesthetic quality $(M=2.90)$, watershed management $(M=2.92)$. 


\section{Conclusion and Recommendations}

The following conclusions could be drawn from the findings of this research work.

- Many farmers in the study area practiced agro forestry while minority are non-agroforestry farmer.

- Farmers have adopted agricultural practices which fit into their socio-economic conditions.

- Many farmers can grow crops, animals and trees in the same piece of land, they use the manure from animals to offset cost of buying fertilizer.

- Agro forestry farmers derived substantial financial benefits.

- Contact with extension agents was relatively poor in the study area.

- Another significant revelation of this study is the way agroforestry farms are managed and sponsored. These are handled entirely by individual farmers and their families.

- Government's involvement is almost not visible.

- Accessibility to land and its resources is restricted by the prevailing land tenure system of the territory which is predominantly inheritance. Immigrant farmers are especially hindered and cannot easily invest in agroforestry.

Household in the study area can gain much from agro forestry practice. Also, the quality of lives of the farmer in the area can also be improved, if the following is done:

1) Agro forestry farming naturally requires large area of land. However, most agroforestry farmers do not have access to such lands. Government should therefore investigate the possibilities of facilitating access to farm lands by reviewing the land tenure act.

.2) Farmers awareness in agroforestry technologies ought to be improved through mass media programmes. These technologies are not as popular as one would expect. Some of the farmers interviewed needed to be educated about agroforestry programmes.

3) Women constitute a very large work force, yet they hardly participate in most agroforestry practices in the study area. This situation ought to be changed as their participation could expand the scope of agroforestry farming and by implication reduce the effect of desertification.

4) Government should motivate agricultural production with more emphasis on agroforestry practices since agroforestry farming combines the production of food, fiber, livestock and protection of the environment. Thus, economic and social assistance should be provided to farmers to enhance adoption of agroforestry practices.

.5) Investigations have revealed that adoption of agroforestry practices was constrained by lack of farm inputs such as high cost of agro chemicals, transportation, theft, pest and diseases etc. The government and concerned agencies should provide these promptly to farmers as incentives to increase their adoption of agroforestry practices.

6) Agro forestry is lucrative in the study area, more people are advised to go into agro forestry practice.

\section{References}

Abumere, S.I. (2008), In Udo, R.K. and mamman, A.B. (eds) Nigeria: Giant in the Tropics Vol. 2 State Surveys, pp. $15-24$

Areola, O (2008). Ecology of Natural Resources in Nigeria, Athenaeum press ltd, Newcastle upon tyne.

Ejaro, S.P. (2000), "Land Administration". in Dawam, P.D. (ed) Geography of Nsukka, Enugu Nigeria, Famous/Asanlu Publishers, pp.158-172

Gaza, L.Z. (2005), "Induced Changes in the Rural Areas of the Enugu state, Nigeria", Unpublished M.Sc. Dissertation, ABU, Zaria Huxley, P. A. (1983). Comments on Agroforestry, classification with Special reference to plant Aspects. In: Plant Research and Agroforestry. ICRAF. Nairobi, Kenya. 161-172

Kang, B. T., Atto-Krah, A. N., and Renoids, L. (1999). Alley Farming. Macmillian education Ltd.

Nair, P. K. R. (1983). Agroforestry with coconuts and other tropical plantation crop. In: Huxley, P. A. (eds) Plant research and Agroforestry. Nairobi, Kenya. 79-102

Obi S.NC (1963), "the Igbo law of property"_Butterworth and co (publishers) ltd.London,UK.

Onumadu, (2001). Forestry Extension: The Missing links. In: Popoola L., Abu, J. E. and Oni, P. I. (eds) Proceedings of the 27 Annual Conference of FAN, Forestry and National Development Abuja, September 17-21, 2001, 
Raintree, J.B., Thomson and Van-Mardell, H. (1984) Agroforestry in West Africa Sahel, National Academy Press, Washington DC

\section{Copyrights}

Copyright for this article is retained by the author(s), with first publication rights granted to the journal. This is an open-access article distributed under the terms and conditions of the Creative Commons Attribution license (http://creativecommons.org/licenses/by/4.0/). 